\title{
COVID-19 sonrası akciğer sekelleri: uzun dönem takip ve tedavi
}

\author{
Haluk TÜRKTAŞ ${ }^{1}(\| \mathrm{D})$ \\ i. Kıvılcım \\ OĞUZÜLGEN ${ }^{1}$ (ID)
}

${ }^{1}$ Gazi Üniversitesi Tıp Fakültesi, Göğüs Hastalıkları Anabilim Dalı, Ankara, Türkiye

${ }^{1}$ Department of Chest Diseases, Gazi University Faculty of Medicine, Ankara, Turkey
Makale atıf: Türktaş $H$, Oğuzülgen iK. COVID-19 sonrası akciğer sekelleri: uzun dönem takip ve tedavi. Tuberk Toraks 2020;68(4):419-429.

Yazışma Adresi (Address for Correspondence)

\section{Dr. Haluk TÜRKTAŞ}

Gazi Üniversitesi Tıp Fakültesi, Göğüs Hastalıkları Anabilim Dalı, ANKARA - TÜRKIYE

e-mail: halukturktas@gmail.com

OTelif Hakkı 2020 Tüberküloz ve Toraks. Makale metnine www.tuberktoraks.org web adresinden ulașılabilir.

\section{ÖZ}

COVID-19 sonrası akciğer sekelleri: uzun dönem takip ve tedavi

COVID-19 pnömonisi geçiren hastalarda uzun dönemde IPF, kronik hipersensitivite pnömonisi ve otoimmun hastalıklarda gördüğümüz hızlı FVC kaybı, tomografide yaygın fibrozis, yaşam kalitesinde azalma ve artmış mortalite ile karakterize progresif irreversible akciğer fibrozisinin gelişip gelişmeyeceği konusunda henüz yeterli kanıt bulunmamaktadır. Ancak yaşlı hastalarda daha az ve non-progresif fibrozisler bile ciddi morbidite ve mortalite nedeni olabilir. Dolayısıyla COVID-19'dan etkilenen milyonlarca insanın varlığı düşünüldügünde nadir görülen bir komplikasyon bile toplum düzeyinde ciddi bir sağlık sorunu olarak karşımıza çıkabilecektir. Konunun önemi nedeniyle COVID-19 sonrası akciğer fibrozisi ve COVID ilişkili trombozis için risk faktörleri, koruyucu önlemler ve tedavisi konusunda çalışmalar hızla planlanıp hayata geçirilmelidir (1). Bu derlemede COVID-19 pnömonisi geçiren hastalarda uzun dönemde oluşabilecek pulmoner fibrozis ve vasküler komplikasyonların (pulmoner emboli, pulmoner hipertansiyon) sıklığı, klinik önemi, korunma ve tedavisi tartışılmıştır.

Anahtar kelimeler: COVID-19 sonrası akciğer sekelleri; pulmoner fibrozis; pulmoner emboli

\section{ABSTRACT}

Post-COVID-19 pulmonary sequla: longterm follow up and management

Though it has been 8 months since the beginning of COVID-19 pandemic, number of cases and deaths are still seriously increasing. We still don't have enough evidence about the prognosis of patients who had COVID-19 pneumonia. In long term follow up we wonder if they will have rapid FVC decline, widespread fibrosis in computed tomography, loss in quality of life or increased mortality that we experience in idiopathic pulmonary fibrosis, chronic hypersensitivity pneumonia or autoimmune interstitial lung diseases. However, in elderly patients less severe dysfunction or non-progressive-fibrosis can cause morbidity and mortality. Therefore, if we consider millions of 
people who are affected by COVID-19, even a rare complication can cause serious health problem in social scale. Because of the importance of this issue randomized controlled trials should be rapidly planned on post-COVID fibrosis, COVID associated thrombosis, risk factors, prevention and treatment (1). In this review, the frequency, clinical importance, prevention and treatment of possible long-term sequels of COVID-19 pneumonia (pulmonary fibrosis, pulmonary embolism and pulmonary hypertension) will be discussed.

Key words: Post-COVID-19 pulmonary sequela; pulmonary fibrosis; pulmonary embolism

\section{Gíriş}

Yeni SARS-CoV-2 virüsünün neden olduğu Coronavirüs Hastalığı 2019 (COVID-19) Dünya'da ilk kez Aralık 2019'da Çin'in Wuhan şehrinden bildirilmiştir. Çok bulaşıcı olan virüs hızla tüm Dünya'ya yayılmış ve 11 Mart 2020 tarihinde Dünya Sağlık Örgütü küresel pandeminin başladığını ilan etmiştir. Pandeminin başlangıcından itibaren geçen yaklaşık sekiz ayda, 9 Kasım 2020 tarihi itibariyle tüm Dünya'dan bildirilen vaka sayısı 50 milyonu ve ölüm sayısı ise 1.250.000'i geçmiş̧ir (2). Aynı zaman diliminde ülkemizde Sağlık Bakanlığı tarafından bildirilen resmi rakamlara göre hasta sayısı 400.000, ölümler ise 11.000 'dir (3). Ancak gerçek rakamların resmi rakamların çok üstünde olduğu bilinmektedir. Aradan yaklaşık sekiz ay geçmesine karşın hala tüm Dünya'da vaka sayılarında ve ölümlerde ciddi artışlar devam etmektedir. Pandemi döneminde ölümlerin azaltılabilmesi için virüsün başta akciğerler olmak üzere tüm sistemlerde neden olduğu akut organ fonksiyon bozukluklarının düzeltilmesi ve tedavi edilmesi ile uğraşılmıştır. Ancak önümüzdeki aylarda ve yıllarda hastalığı ağır geçiren kişilerde virüsün akciğerlerde ve diğer organlarda neden olduğu kronik değişiklikler ve sekellerin tanı ve tedavisi önemli olacaktır.

\section{PULMONER FIBROZIS}

COVID-19 pnömonisinde akut dönemde hastalığın radyolojik seyri izlendiğinde, başlangıçta en sık görülen tomografik bulgular alt zonlarda bilateral subplevral buzlu cam görünümü ve konsolidasyondur. Fokal ödem, organize pnömoni ve diffüz alveolar hasar radyolojik bulguların altta yatan nedenleridir $(4,5)$. Hastaların çoğunda tomografik görüntülerin düzelmesi zaman almaktadır. Semptomların başlangıcından yaklaşık 4-14 gün sonra tomografik bulgular kaldırım taşı görünümü kazanabilmekte ve iki haftadan sonra yavaş yavaş silinmeye başlamaktadır. Ancak bazı hastalarda erken dönemde çekilen tomografilerde bile fibrotik çizgilenmeler, bronşiektaziler görülebilmektedir (6-8).

\section{COVID-19 Pnömonisinin Erken Dönem Seyri}

Henüz bir yılını doldurmamış olan COVID-19 pandemisinde çalışmaların tamamında bu 7-8 ay içerisindeki erken ve orta dönem komplikasyonlar araştırılabilmiştir. Daha uzun dönemde ortaya çıkabilecek sekeller ile ilgili bilgiler ise ancak önümüzdeki yıllarda hastaların izlenmesi sonucu elde edilecektir.

Erken dönem değişiklikleri araştırmak amacıyla 90 hastanın incelendiği bir çalışmada ortalama 24 gün sonra taburcu edilen hastaların \%94'ünde hala radyolojik değişikliklerin, ağırlıklı olarak buzlu cam görünümünün devam ettiği belirtilmektedir (9). Diğer bir çalışmada ortalama 27 gün hastanede yattıktan sonra taburcu edilen 110 hastada taburculuk sırasında yapılan solunum fonksiyon testleri incelenmiş, 110 hastadan pnömonisi olmayan 24 hasta ile pnömonisi olan 67 ve ağır pnömonisi olan 19 hastanın SFT bulguları karşılaştııılmıştır. Pnömonisi olmayanların \%30'unda, pnömonisi olanların \%42'sinde ve ağır pnömonisi olanların \%82'sinde diffüzyon kapasitesi düşük bulunurken, total akciğer kapasitesi ağır pnömonili hastaların \%47'sinde normalin altında bulunmuştur. SFT parametreleri açısından fark olmadığı görülmüştür (10). Bunların aksine diğer bir çalışmada ise mekanik ventilasyon gerekmeyen ağır COVID-19 pnömonisi ile tedavi edilip taburcu edilen hastalarda taburculuktan sonraki 6 . haftada yapılan solunum fonksiyon testlerinde azalmaların olmadığı görülmüştür (11).

COVID-19 pnömonisinin akciğerlerde fibrotik sekel bırakıp bırakmadığını araştırmak amacıyla planlanan birçok prospektif çalışma mevcuttur. Bunlardan Avusturya'da planlanan bir çalışmada hastaneden taburcu edildikten sonra persistan solunum sistemi semptomları olan 130 hastada taburculuktan sonra birinci, üçüncü ve altıncı aylarda SFT ve HRCT ile kontrollerin yapılması planlanmış olup halen çalışma devam etmektedir (NTC04416100). íspanya'da başlanan diğer bir çalışmada ise COVID-19 pnömonisinin akciğer fibrozisi ile olan ilişkisini araştırmak amacıyla 
hastaneden taburcu olan hastalarda taburculuktan sonra 4, 12, 26 ve 52. haftalarda SFT değişiklikleri ve restriktif bozukluğu olanlarda HRCT ile akciğerlerin değerlendirilmesi planlanmıştır (NCT04409275). Aynı amaçla Fransa'da planlanan bir çalışmada COVID-19 pnömonisi geçiren 100 hastada taburculuk sırasında, 3 ay ve bir yıl sonra çekilecek toraks tomografisi ile hastalığın seyrini ve akciğer fibrozisi görülme sıklığını belirlemek amaçlanmıştır (NTC04483752).

\section{SARS ve MERS Salgınlarından Neler Öğrendik}

COVID-19 pnömonisinde uzun dönem komplikasyonların ne sıklıkta görülebileceği henüz net değildir. Ancak SARS-CoV-1 ile SARS-CoV-2 virüslerinin filogenetik benzerlikleri ve bu virüslerin neden olduğu Severe Acute Respiratory Syndrome (SARS) ve Middle East Respiratory Syndrome (MERS) pnömonilerinin klinik, radyolojik ve patolojik olarak COVID-19 pnömonisi ile çok benzer özellikler göstermesi progresyon riskinin de benzer olabileceğini düşündürmektedir (12). Dolayısıyla SARS ve MERS'in uzun dönem komplikasyonlarını araştıran çalışma sonuçları COVID-19 pnömonisinin uzun dönem sekellerini anlamamıza yardımcı olmaktadır.

SARS'lı hastaların \%36'sında taburculuktan 3 ay sonra akciğer grafisinde retiküler görüntülerin varlığı ve 6. ayda hastaların \%30'unda retikülasyon ve alveoler gölgelenmelerin hala devam ettiği görülmüştür. Altıncı ayda hastaların \%16'sında DLCO'da azalmaların olduğu saptanmış ve bu da radyolojik lezyonların fizyolojik bozukluklara neden olabileceği şeklinde yorumlanmıştır (13).

Çin'de 2003 yılında SARS pnömonisi geçiren ve tedavisinde yüksek doz kortikosteroid kullanılan 71 hasta 2018 yılına kadar 15 yıl süre ile izlenmiştir. 2003 yılında hastaların SARS pnömonisi nedeniyle hastanede yatış süreleri ortalama 33 gün olup, bu hastalar ortalama 160 mg/gün steroid kullanmışlardır. Kullanılan kümülatif steroid dozu 3.450 mg'dır. Hastalara 3. yıl ve 15. yılda solunum fonksiyon testi yapılmıştır. 3. yılda hastaların \%22'sinde restriktif tipte solunum fonksiyon testi bozukluğu saptanırken 15. yılda hiçbirisinde restriktif bozukluk saptanmamıştır. Ancak hastaların yaklaşık üçte birinde 15 yılın sonunda hafif de olsa diffüzyon kapasitesinin azaldığı görülmüştür. 2003 ve 2018 yılında toraks tomografisi çekilen 27 hastada radyolojik bulguların özellikle ilk iki yılda daha belirgin azaldığı ve daha sonraki yıllarda stabil seyrettiği görülmüştür. Bu hastalarda akciğer fibrozisinin daha az görülmesi yüksek doz steroid kullanımına bağlanmıştır. Ancak hastaların yaklaşık \%20'sinde kullanılan yüksek doz steroide bağlı femur başı nekrozu görülmüştür (14).

SARS geçirip hayatta kalan 97 hastanın bir yıl sonunda yapılan incelemelerinde hastaların \%28'inde akciğer grafisinde sekel lezyonların devam ettiği, \%4'ünde FVC'nin, \%24'ünde diffüzyon kapasitesinin normal değerlerin altında olduğu ve radyolojik bulgular ile solunum fonksiyon bozukluğunun korele olduğu görülmüştür (15). Diğer bir çalışmada iki yıl izlenen 55 SARS'lı hastanın \%16'sında FVC, $\% 11^{\prime}$ inde TLC ve \%53'ünde DLCO normal değerlerin altında bulunmuş ve bu da uzun dönemde solunum fonksiyonlarında kalıcı değişikliklerin olduğunun göstergesi olarak kabul edilmiştir (16).

MERS'te ise sağ kalan hastaların \%36'sında 6. haftada tomografide sekel görüntülerin varlığı gözlenmiştir (17).

Bu bulgular COVID-19 ile enfekte olan SARS ve MERS'li hastaların büyük çoğunluğunda hastaneden taburcu oldukları sırada radyolojik bulguların devam ettiğini, ancak taburculuktan 3 ay sonra hastaların üçte ikisinde radyolojik bulguların normale döndüğünü, hastaların yaklaşık \%30'unda radyolojik ve fizyolojik bozuklukların devam ettiğini göstermektedir.

\section{Akciğer Fibrozisi Açısından Hastaların İzlemi}

COVID-19'da hastaların en önemli hastaneye yatış nedeni pnömonidir. Pnömoni nedeniyle hastaneye yatan hastaların yaklaşık \%4-5'inde ARDS gelişmekte ve hastaların bir kısmı akut solunum yetmezliği nedeniyle kaybedilmektedir. Hastalığın erken dönem klinik bulguları iyi bilinmekle birlikte, ağır pnömoni geçirip hayatta kalan hastalarda uzun dönemde akciğerlerde ne gibi sekeller bırakacağı konusu net değildir. SARS ve MERS salgınlarından sonra yapılan gözlemsel çalışmalar bu konuda bize ayrıntılı bilgiler vermiştir, ancak önümüzdeki yıllarda COVID-19 pnömonisi geçiren hastaların uzun dönem takiplerinden elde edilecek sonuçlar bu konunun aydınlatılmasında yardımcı olacaktır. Bu nedenle COVID-19 pnömonisi geçiren hastalarda akciğer fibrozisi gelişip gelişmediğini belirlemek amacıyla bir takip stratejisi oluşturulması ve risk grubu hastalarda akciğer fibrozisi gelişmesini önlemek için erken ve uygun tedavilerin başlanması önem kazanmaktadır.

Günümüzde COVID-19 pnömonisi geçiren hastalarda oluşabilecek pulmoner komplikasyonların izlen- 
mesinin hangi sıklıkta ve hangi yöntemlerle yapılması gerektiği konusunda bir görüş birliği yoktur. Hastaların çoğunda erken dönemde radyolojik düzelme olmaktadır. Erken dönem kontrol için ideal zamanın taburcu olduktan sonraki ikinci hafta olduğu belirtilmektedir (18). Öne sürülen bir hipoteze göre akciğer lezyonlarının süresi ve kalıcı olup olmayacağı COVID-19 pnömonisinin akut dönemdeki ağıllığı ile ilişkilidir. Hastaneye yatış gereği olmadan pnömoniyi ayakta geçiren hafif hastalarda yaklaşık 6 ay, hastaneye yatan ancak yoğun bakım gereksinimi olmayan orta ağırlıkta hastalarda 12 ay içerisinde radyolojik tam düzelme beklenmektedir. Mekanik ventilasyon gerektiren ağır hastalarda ise restriktif akciğer hastalığı, azalmış diffüzyon kapasitesi ve tomografide fibrozis beklenen bir sonuçtur. Buna göre akciğerlerdeki sekel fibrotik lezyonların silinmiş, kısmen düzelmiş, değişmemiş ya da ilerlemiş mi olduğuna karar vermek için taburculuktan sonra 6 ve 12. ayda, lezyonları devam eden hastalarda uzun dönem progresyonun saptanabilmesi için 24 ve 36 . ayda kontrastsız HRCT çekilmesi önerilmektedir (19).

Bu konuda British Thoracic Society (BTS)'nin yayınladığı kılavuz yol gösterici olacaktır (20). Kılavuz önerileri aşă̆ıda özetlenmiş̧tir.

A) Pnömonisi olmayan, ya da pnömonisi olup taburculukta radyolojik olarak tamamen düzelen hastalar

Bu grup hastalarda periyodik uzun dönem izlem ve akciğer grafisi kontrollerine gerek yoktur.

B) Yoğun bakıma yatış gereği olmamış, hafif-orta ağırlıkta COVID-19 pnömonisi geçirip taburcu edilen hastalar

a) Hafif, orta ağılıkta pnömonisi olup tedaviden sonra taburcu edilen hastaların kontrolleri taburculuktan sonra 3. ayda yapılmalıdır. Çekilen akciğer grafisi taburculuk filmi ile karşılaştırılmalı, lezyonları tamamen kaybolan hastalar izlemden çıkarılmalıdır. COVID-19 pnömonili hastaların büyük çoğunluğunda periyodik kontrollerin 3. aydan sonra sonlandırılması beklenmektedir.

b) 3. ayda belirgin radyolojik bulguları olan hastalarda solunum fonksiyon testleri yapılmalı, 6 hafta sonra tekrar akciğer grafisi ile değerlendirilmeli, akciğer grafisi normale dönmüş ise takipten çıkartılmalıdır. Eğer lezyonları devam ediyor ise veya solunum fonksiyon testi bozuklukları, ya da açıklanamayan nefes darlığı var ise interstisyel akciğer hastalığı ve pulmoner emboli açısından toraks HRCT ve BT anjio ile birlikte EKO ve egzersizde kan gazları bakılmalı ve inceleme sonucunda interstisyel akciğer hastalığı veya pulmoner emboli ile uyumlu olan hastalar bu konular ile ilgili merkezlere yönlendirilmelidir. Semptomu ve fonksiyon bozukluğu olan ancak emboli ve interstisyel akciğer hastalığı saptanmayan hastalarda başka nedenler araştırılmalıdır.

\section{C) Yoğun bakımdan taburcu edilmiş ağır pnömoni geçirmiş olan hastalar}

a) Bu grup hastalar erken dönemde, taburculuktan 4-6 hafta sonra değerlendirilmeli, daha sonra 3. ayda akciğer grafisi çekilmeli, grafi normal ve asemptomatik olan hastalar takipten çıkarılmalıdır.

b) Akciğer grafisinde lezyonları gerilemeyen ve/veya semptomları devam eden hastalarda interstisyel akciğer hastalığı ve pulmoner emboli açısından toraks HRCT ve BT anjio ile birlikte solunum fonksiyon testleri, EKO, egzersizde kan gazları bakılmalı ve inceleme sonucunda interstisyel akciğer hastalığı veya pulmoner emboli ile uyumlu olan hastalar bu konular ile ilgili merkezlere yönlendirilmelidir. Semptomu ve fonksiyon bozukluğu olan ancak emboli ve interstisyel akciğer hastalığı saptanmayan hastalarda başka nedenler araştırılmalıdır.

c) 3. ayda klinik olarak düzelen ancak akciğer grafisinde lezyonları devam eden hastalar olabilmektedir. Bu hastalarda ise 6-8 hafta sonra tekrar akciğer grafisi çekilerek değerlendirilmeli ve lezyonları devam eden hastalarda $b$ şıkkında önerilen yol izlenmelidir.

\section{Akciğer Fibrozisinin Gelişmesinin Önlenmesi ve Tedavisi}

COVID-19 pnömonisi sonrası gelişebilecek olan akciğer fibrozisinin önlenmesi ve tedavisi konusunda yeterli çalışma ve kanıt olmamakla birlikte dört bileşenli bir yaklaşım önerilmektedir $(21,22)$ (Şekil 1).
a) Fibrozis için risk faktörlerinden kaçınma
b) Viral replikasyonun önlenmesi
c) İnflamatuar yanıtın baskılanması
d) Antifibrotik tedavi

\section{a) Koruyucu önlemler:}

COVID-19 pnömonisi olan hastalarda hastanın yaşı, hastalığın ağırlığı, bakteriyel süperenfeksiyon, yoğun bakımda kalış süresi, mekanik ventilasyon uygulanmış olması, altta yatan akciğer hastalığının varlığı ve inflamasyon belirteçlerinin aşırı yüksek bulunması 


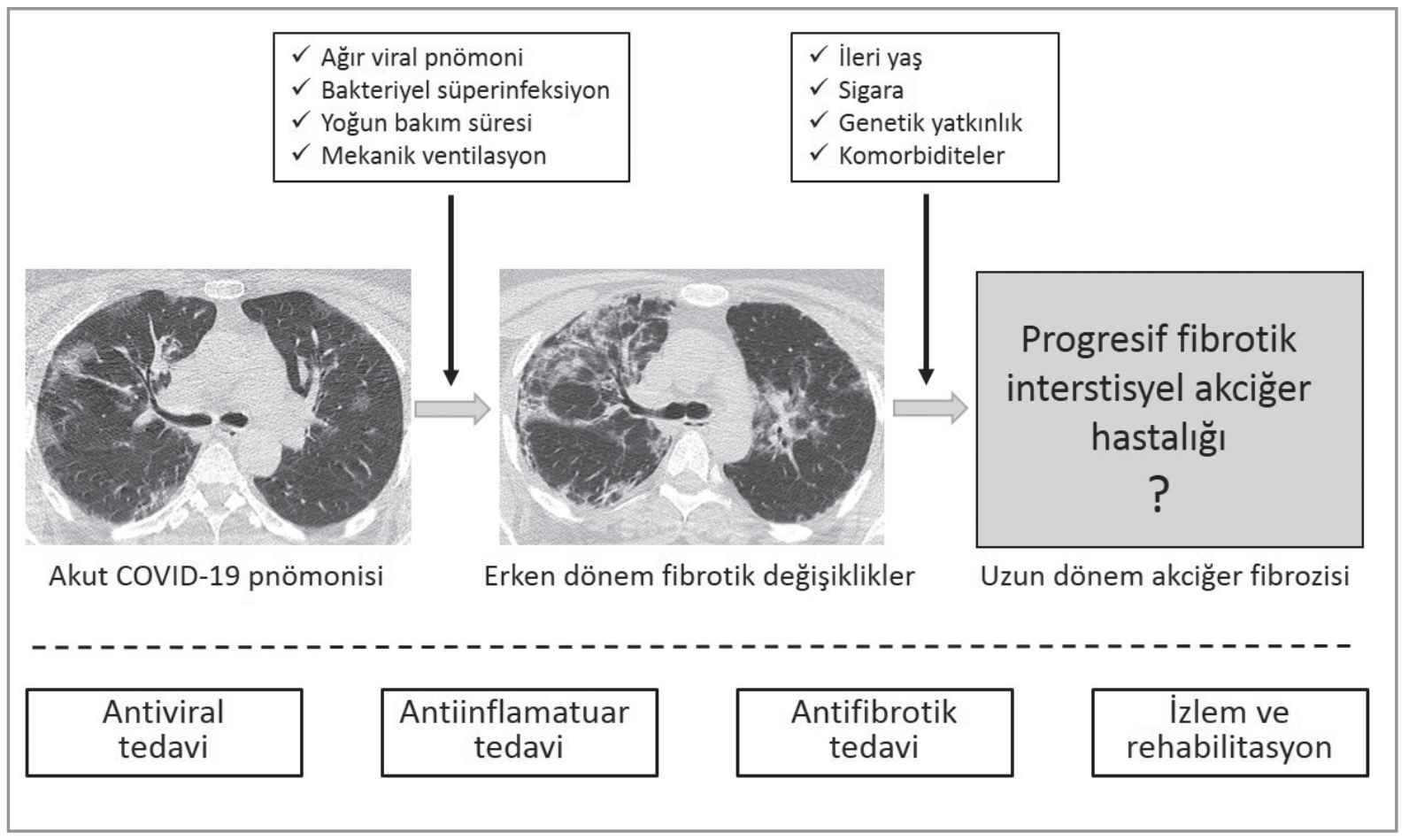

Şekil 1. Hipotetik olarak COVID-19 pnömonisinin fibrozise progresyonu, önlem ve tedaviler.

akciğer fibrozisinin gelişmesinde etkili faktörler olabilir (22-25). Alveol hasarının, dolayısıyla fibrozisin en aza indirilebilmesi için hastalarda mümkün olduğu kadar yoğun bakım yatış sürelerinin kısaltılması, mutlak gerekmedikçe mekanik ventilasyondan kaçınılması, mekanik ventilasyon süresinin azaltılması ve düşük tidal volüm ve hava yolu basıncı kabul edilebilir sınırlarda tutularak koruyucu ventilasyon uygulanması yararlı olabilir.

\section{b) Antiviral tedaviler:}

Akciğer fibrozisinin önlenmesinde viral yükün azaltılması ve viral pnömoni süresinin kısaltılması önemlidir. Günümüzde erken başlanan ve uzun süre kullanılan antiviral ilaçların (Favipiravir, Remdesevir gibi) akciğer fibrozisi gelişmesinde önleyici bir etkisinin olup olmadığı ve bu etkinin farklı antiviral ilaçlar arasında farklılıklar gösterip göstermediği bilinmemektedir.

\section{c) Anti-inflamatuar tedaviler:}

Kortikosteroidler: Akut dönemde kortikosteroid kullanımının kritik ve ağır hastalarda 28 günlük mortalitede anlamlı azalmalara neden olduğunun gösterilmesi üzerine Dünya Sağlık Örgütü, Eylül 2020 tarihinde COVID-19'da kortikosteroidlerin kullanımı konusunda bir kılavuz yayınlamıştır. Bu kılavuzda iki öneride bulunulmaktadır. 1) Kritik ve ağır hastalarda sistemik kortikosteroidlerin 7-10 gün süreyle kullanılması kuvvetle önerilir. (Örn: günlük $6 \mathrm{mg}$ oral veya intravenöz deksametazon, veya 8 saatte bir $50 \mathrm{mg}$ intravenöz hidrokortizon). 2) Ağır olmayan COVID$19^{\prime}$ da ise sistemik kortikosteroid kullanılmaması koşullu olarak önerilir (26). Bu öneriler akut dönemde steroid kullanımına açıklık getirirken fibrozisi önlemek için daha uzun süreli kullanım konusunda elimizde yeterli kanıt bulunmamaktadır. Diğer nedenlere bağlı ARDS'de, özellikle sepsis sonrası gelişen ARDS'de kortikosteroid kullanımının akciğerlerde kalıcı yapısal değişiklikleri önlediğini gösteren çalışmalar mevcuttur (27). Bu çalışma sonuçları genellenerek COVID-19 pnömonisinde de fibrozisi engellemek için akut dönem sonrası oral steroid kullanımı teorik olarak mantıklı gelmektedir. Ancak steroidlerin virüs replikasyonuna olumsuz etkilerinin olup olmadığı kesin olarak bilinmemektedir.

Steroid tedavisinin COVID-19 sonrası oluşan akciğer fibrozisine etkisini araştıran ve henüz yayımlanmayan bir çalışmada COVID-19 nedeniyle hastanede yatarak tedavi gören ve kontrol tomografilerinde sekel lezyonları olan 450 hastaya 14 gün süre ile günde $20 \mathrm{mg}$ oral prednizolon verilmiş ve tedavi 
sonrası tomografik lezyonlarda düzelme olup olmadığına bakılmıştır. (NCT04551781).

Antisitokinler: İnhalasyon ile hava yollarına gelen SARS-CoV-2 virusu epitel hücrelerinde bol miktarda bulunan ACE2 reseptörüne bağlanıp hücre içine girerek çoğalır. Ortalama bir hafta süren ateş, halsizlik, myalji gibi semptomların ardından bazı hastalarda öksürük, nefes darlığı eklenerek pnömoni tablosu ortaya çıkar. Pnömonili hastaların bir kısmında ise klinik tablo kötüleşerek mekanik ventilasyon gerektiren ağır pnömoniler oluşabilir. Hastalığın solunum yetmezliğine progresyonu birçok inflamatuar belirteçlerin ve sitokinlerin yükselmesine paralel olarak ortaya çıkar. Kliniğin ağırlaşması ile ilişkili olabileceği düşünülen iki proinflamatuar sitokin IL-1 ve IL-6'dır. Viral pnömoninin ağır geçirilmesinin uzun dönemde akciğerde sekellerin kalmasında rol oynayan bir risk faktörü olduğu varsayılmaktadır. Bu varsayım nedeniyle özellikle yoğun inflamasyon ile seyreden ağır pnömonili hastalara da antisitokin tedaviler (Anti IL-1 (Örn: Anakinra) ve anti IL-6 (Örn: Tocilizumab) uzun dönemde ortaya çıkacak fibrotik sekelleri önleyebilir. Ancak bu konuda yapılmış bir çalışma ve kanıt yoktur (28).

\section{d) Antifibrotik tedaviler:}

Antifibrotik ilaçlar yaklaşık 4-5 yıldır IPF tedavisinde kullanılmaktadır. Antifibrotiklerin IPF'de FVC kaybın$\mathrm{da}$, hastane yatışlarında ve mortalitede anlamlı azalmalar sağladığını gösteren bir çok çalışma yayınlanmıştır $(29,30)$. Hipersensitivite pnömonisi, otoimmun interstisyel akciğer hastalıkları, idiopatik fibrotik NSiP, sınıflandırlamamış interstisyel pnömoniler gibi fibrotik interstisyel akciğer hastalıklarının prognozu iPF'den farklı olup genellikle daha iyi seyirlidir. Ancak bu grup hastalıkların yaklaşık üçte birinde hastalık IPF gibi progresif seyir gösterebilmektedir. Son yıllarda progresif fibrotik seyir gösteren IPF dışı fibrotik interstisyel akciğer hastalıklarında antifibrotik tedavilerin hastalığın progresyonunu önlemede yararIı olduğunu gösteren çalışmalar yayımlanmıştır $(31,32)$. Bu çalışmalarda FVC'de yıllık \%10'dan fazla kayıp, ya da FVC'de yıllık \%5-10 arası kayıp olan hastalarda buna ek olarak DLCO'da \%15'ten fazla kayıp, veya klinik ve radyolojik progresyon kriter olarak alınmıştır.

COVID-19 pnömonisine bağlı gelişen akciğer fibrozisinin tedavisinde antifibrotik ilaçların etkinliği konusunda henüz elimizde kanıt bulunmamaktadır. Etkinliğini gösteren çalışmalar yayımlanmadan anti- fibrotik ilaçların COVID-19 sekellerin tedavisinde kullanılması önerilmez. Önümüzdeki yıllarda, yukarıda sözü edilen çalışmalar doğrultusunda, ancak progresif seyreden yaygın fibrozis sekellerinde gündeme gelecektir (33).

Bu konuda planlanan ve yürütülen çalışmaların bir çoğu önümüzdeki aylar ve yıllar içerisinde sonuçlanacaktır. Bunlardan ilki orta ve ağır COVID-19'da gelişen pulmoner fibrozisli hastalarda Nintedanib'in etkinliği ve yan etkilerinin araştırılmasını planlayan bir çalışmadır. Çalışmaya 96 hasta alımı planlanmakta, çalışma süresi 8 hafta ve primer sonlanım noktası FVC'deki değiş̧imdir (NCT04338802). Diğer bir çalışma Nintedanib'in COVID-19'da akciğer fibrozisinin progresyonunu yavaşlatıp yavaşlatmayacağını araştırmak amacıyla planlanmıştır. Çalışmaya son 2-6 ay içerisinde PCR pozitif COVID-19 tanısı ile hastanede yatarak tedavi gören, HRCT'de fibrotik özellikteki lezyonları \%10'dan fazla olan ve DLCO değeri beklenenin \%70'ten küçük olan 250 hasta alınması planlanmakta olup çalışma süresi 12 ay ve primer sonlanım noktası FVC değişimidir (NCT04541680).

Pirfenidon ile planlanan bir çalışmada ağır COVID19 pnömonisi ve ARDS tanısı ile tedavi edilip taburcu edilen ve tomografide \% $\%$ ten fazla fibrotik değişiklikleri olan 148 hastada 24 hafta süre ile verilen Pirfenidon'un etkinliğinin araştııılması planlanmıştır. Bu çalışmada sonlanım noktası FVC kaybında azalma ve HRCT bulgularında düzelmedir (NCT04607928). Diğer bir çalışmada 294 hastanın yarısı standart tedavi alırken diğer yarısına Pirfenidon eklenmesi planlanmış. Tedavi süresi 4 hafta ve üzeri olup sonlanım noktası HRCT'de lezyonların değişimidir (NCT04282902).

Ağır COVID-19 pnömonisi geçiren hastalarda genellikle hastalık seyri üç aşamalı olmaktadır. Bu aşamaları şöyle sıralayabiliriz; asemptomatik ya da hafif semptomların olduğu dönem, ardından sitokin fırtınasının ve ağır klinik tablonun geliştiği hiperinflamatuar dönem, daha sonra da fibrotik dönem. IPF tedavisinde kullanılan antifibrotik bir ilaç olan Pirfenidon'un antifibrotik etkisinin yanısıra IL-1 ve TNF-alfa gibi sitokinleri inhibe ederek antiinflamatuar etki gösterdiği de bilinmektedir. Henüz hiç bir kanıt olmamasına karşın teorik olarak Pirfenidon'un bu iki yönlü etkisi nedeniyle COVID-19 pnömonisinin hiperinflamatuar döneminde antiinflamatuar ilaçlar ile birlikte, fibrotik dönemde ise tek başına kullanılabileceği öngörülmektedir $(34,35)$. 
COVID-19 pnömoni sekelinde antifibrotik tedavinin kullanılabileceği konusunda öne sürülen hipotezler ve planlanan çalışmalara karşın antifibrotik tedaviye gerek olmadığını savunan görüşler de mevcuttur. Bu görüşe göre IPF'de fibrozis alveol epitelinin kronik zedelenmesi ve bu zedelenmeyi onarmak için ortaya çıkan anormal ve abartılı yanıt sonucu oluşmaktadır. IPF'de görülen fibrozis hücreden fakir, yaygın, irreversibl ve progresiftir. Bu nedenle hastalığın progresyonunu yavaşlatmak için tedavide antifibrotik ilaçlar kullanılır. COVID-19'da ise yoğun inflamasyonun rol oynadığı viral pnömoni ve ARDS akciğer fibrozisinin nedenidir. Yapılan bir çok çalışmada ARDS'den hayatta kalan hastalarda yaygın progresif akciğer fibrozisinin görülmediği belirtilmektedir. Dolayısıyla COVID-19'da sınırlı sekel fibrotik lezyonlar olabileceği, iPF'de olduğu gibi fizyolojik bozukluklara neden olan, yaşam süresini ve yaşam kalitesini azaltan progresif yaygın fibrozisin olmayacağı ve bu nedenle de antifibrotik tedaviye gerek olmadığı iddia edilmektedir (35).

Ayrıca, antikuagulan kullanan, ishali, karaciğer fonksiyon bozuklukları olabilen akut dönem COVID-19 pnömonili hastalarda antifibrotik ilaçların benzer yan etkileri, klinik tablonun bozulmasına da neden olabilir.

\section{Olası antifibrotik etkinliği olan ilaçlar:}

COVID-19 pnömonisinde Renin-Anjiotensin sistemindeki dengesizliğin akciğer fibrozisine neden olabileceği konusunda görüşler mevcuttur. Erken dönemde virüs ile host arasındaki bağlantı tip II pnömositlerde bol miktarda bulunan Anjiotensin Converting Enzim (ACE2) aracılığı ile olur. Anjiotensin Converting Enzim (ACE) Anjiotensin I'i anjiotensin II'ye dönüştürür. Vazokonstriktör bir peptid olan Anjiotensin II inflamasyon ve fibroziste önemli rol oynar. Anjiotensin II ACE2 aracılığı ile Anjiotensin 1-7'ye hidrolize edilir. Anjiotensin 1-7 ise fibrozisi önleyici yolakları harekete geçirir. Öne sürülen hipoteze göre ACE2 reseptörüne bağlanan virüs $\mathrm{ACE} /$ ACE2 aksında dengesizliğe neden olarak fibrozis gelişmesinde rol oynayabilir ve hastalara Anjiotensin 1-7 verilmesi ile fibrozis önlenebilir (36).

Aldesteronun fibrozis patogenezinde rol oynadığını ve dolayısıyla bir mineralokortikoid reseptör antagonisti olan Spirinolakton'un fibrozis gelişmesini engelleyebileceğini gösteren hayvan deneyleri mevcut olup henüz yapılmış bir klinik çalışma yoktur (37-39).

\section{PULMONER EMBOLI}

\section{Epidemiyoloji}

COVID-19'lu hastalarda yapılan otopsi çalışmalarında makro ve mikrotrombüs insidansının \%58'e kadar çıkabilen yüksek oranlarda olduğu gösterilmiştir $(40,41)$. Yatarak tedavi gören COVID-19 hastalarında VTE insidansı, SARS ve MERS-CoV viral pnömonilerine benzerlik göstermektedir. COVID-19'lu hastalarda hiperkoagülabilite belirteçleri olan D-Dimer, fibrinojen ve faktör VIII düzeyleri artmış, aPTT kısalmış bulunmaktadır (B).

Standart tromboprofilaksi kullanılan bir çalışmada ağır pnömonisi nedeniyle yoğun bakım ünitesinde takip edilen COVID-19 hastalarında VTE insidansı $\% 27$, profilaksi verilmeyen başka bir çalışmada ise insidans \%25 bulunmuştur (42-44).

\section{Patogenez}

Yapılan çalışmalarda COVID-19'u ağır geçiren hastalarda koagülasyon aktivasyonunun sık ve yoğun olduğu görülmüştür (45-47). Otopsi çalışmalarında pulmoner damar yatağı boyunca yaygın mikrotrombüslerin varlığının gösterilmiş olması COVID-19 patogenezinde vaskülopatinin önemli olduğunu düşündürmektedir (48) (K9). Bu post-mortem çalışmalar, ayrıca ciddi endotelyal hücre hasarının varlığının da altını çizmektedir. Buna kanıt olarak apoptozis ve zonula okludens (tight junction) kaybının olduğu gösterilmiştir. Bu bulgular SARS-CoV-2 infeksiyonu ilişkili anormal pulmoner intravasküler koagülopatide endotel hücrelerinin orkestra şefi rolü oynadığını düşündürmektedir (49).

COVID-19 ilişkili endotelyopati olarak tanımlanan bu durumun etyopatogenezinde hastalığın ağırlığı ile korele olarak artan plazma vonWillebrand factor (VWF) ve P-selektin konsantrasyonlarının artışının rol oynadığı düşünülmektedir.

Proinflamatuar sitokinler, hipoksi, kompleman artışı, NETosis (nötrofil ekstraselüler trap aktivasyonu ve salınımı), endotel hasarı ve aktivasyonunu tetikleyen çoklu yolaklardır. Bunların sonucunda VWF ve P-selektin konsantrasyonları artarak mikrovasküler trombüs oluşumu tetiklenmektedir. Endotel hücre yüzeyinden trombomodulin dökülmesi, pulmoner damar yatağı içinde prokoagülan ve pro-inflamatuar bir ortamın oluşmasına katkı sağlamaktadır. Sonuç olarak endotel hücre hasarı ile hücreler bazal membrandan ayrılmakta, zonula okludenslerin kaybı ile vasküler permeabilite de artmaktadır $(45,50)$. 
Ekstrapulmoner organlarda virüs olmaksızın tromboz ve hasar varlığı, SARSCoV-2 enfeksiyonunun hipoksinin de tetiklediği yoğun bir inflamatuar yanıta neden olarak hiperkoagülasyona ve iskemiye neden olduğunu düşündürmektedir.

\section{Profilaksi ve Tedavi}

COVID-19 hastalarında standart heparin (SH) veya düşük molekül ağırlıklı heparinler (DMAH) ile tromboflaksi gerekliliği konusunda fikir birliği olmasına karşın, doz konusunda farklı görüşler vardır. Bazı rehberler dahili hastalarda kullanılan profilaksi dozunu (örn: enoxaparin 40 mg/gün) önerirken bazı rehberler özellikle ağır hastalarda (D-Dimer $>$ normalin 2-6 katı, sepsisle indüklenen koagülopati skoru $\geq 4$ ) orta doz ile profilaksi önermektedir (örn: enoxaparin 2x 40 mg/gün veya 60 mg/gün) Dozun vücut ağırlığına, böbrek fonksiyonlarına ve trombosit sayısına göre ayarlanması önerilmektedir (42,51-53).

\section{Pulmoner Emboli Açısından Hastaların İzlemi}

Hastalığın akut döneminden sonra bir süre daha hastaların hiperkoagülasyon fazında kalabilecekleri düşünülmektedir. Dolayısıyla böyle bir risk taşıyan hastalarda uzatılmış tromboprofilaksi düşünülebilir. Bu konuda da rehberler arasında fikir birliği yoktur.

Taburculuktan sonra evde profilaksiye devam edilmesini savunanlar, daha önce medikal hastalarda yapılan profilaksi çalışmalarının olumlu sonuçlarını referans almaktadırlar. Ayrıca profilaksi verilmeyen benzer durumdaki medikal hastalarda taburculuktan sonra erken dönemde fatal PE riskinin yüksek olduğu gösterilmiştir. Bu nedenle rehberler özellikle VTE açısından yüksek riskli COVID-19 hastalarında (önceden VTE öyküsü, kanser, immobilizasyonun devam etmesi, hastanın yoğun bakımdan çıkmış olması, ileri yaş, D-dimer düzeyinin > normalin 2 katı olması, Modifiye IMPROVE-VTE skoru $\geq 4$ olması) VTE riski, antikoagülana bağlı kanama riskinden de fazlaysa kar/zarar oranı dikkate alınarak profilaksinin DMAH veya DOAK (enoxaparin 6-14 gün, rivaroksaban 31-39 gün; betriksaban 35-42 gün boyunca) ile evde devam edilmesini önermektedirler $(42,51,53-57)$.

Taburculuk sonrasında tromboprofilaksiye devamı önermeyenler ise gerekçe olarak COVID-19 hastalarının özelinde taburculuk sonrası tromboz riskinin yüksek olduğuna dair kesin veri olmamasını ve verilecek antikoagülanın kanama riskini göstermektedirler (52).

Pnömonisi olmayan ve COVID-19'u hafif geçiren olgular için tromboprofilaksi önerilmemektedir. Yine antiagregan ve antiplatelet ajanların tromboprofilaksi amaçlı COVID-19 hastalarına başlanması, yatan hastalarda veya taburculuktan sonra tromboprofilakside önerilmemektedir (51). Daha önce başka nedenlerle bu tedavileri alan hastalarda ise tedavi kesilmemelidir. COVID-19 hastalarında venöz tromboembolism önlenmesinde, standart heparin, inhale standart heparin, enoksaparin ve asetil salisilik asitin karşılatırılmasını planlayan çalışma halen devam etmektedir (NCT04466670). Yine Kopidogrel'i DMAH ve standart heparinle karşılaştıran (NCT04409834) çalışma da devam etmektedir.

Akut COVID-19 geçirirken pulmoner tromboemboli (PE) tanısı alan hastaların tedavi ve takipleri PE rehberlerindeki protokollere göre yapılmalıdır. Takiplerinde PE'nin yegane komplikasyonu olan pulmoner hipertansiyon $(\mathrm{PH})$ geliştiği düşünülen hastalar PH merkezlerine refere edilmelidirler. COVID-19 enfeksiyonu sırasında PE geçiren hastalarda takipte ne sıklıkta kronik tromboembolik PH (KTEPH) geliştiğine dair bir veri bulunmamaktadır. Belirgin rezidü trombüsü kalmadıysa ve KTEPH şüphesi yoksa antikoagülan tedavi 3 ayın sonunda kesilmelidir.

PE tanısı konup semptomları devam eden olgular KTEPH açısından EKO kardiyografi, BT anjiografi ve ventilasyon-perfüzyon (V/Q) sintigrafisi ile değerlendirilmelidirler. Ancak COVID-19'a bağlı parankimde sekel lezyonlar/fibrozis gelişen hastalarda V/Q sintigrafisinin kullanılması yanlış değerlendirmelere neden olabileceği için önerilmemektedir.

Olası kronik tromboembolik hastalık ve KTEPH tanısı koyma veya dışlamada D-Dimer kullanılmamalıdır. COVID-19 hastalığı sonrasında antikoagülan tedavinin kesilmesinde D-Dimer seviyelerine göre karar vermekle ilgili yaklaşımı destekleyen bir veri yoktur.

Çünkü D-Dimer COVID-19'da genellikle non-spesifik akut faz reaktanı olarak yükselmektedir ve yüksekliği kötü prognozla ilişkilidir (58). 1099 hastanın dahil edildiği bir COVID-19 serisinde hastaların \%46'sında D-Dimer yüksek bulunmuştur (59). 198 hastanın dahil edildiği başka bir seride hayatta kalan hastaların D-Dimer seviyelerin kaybedilen hastalara göre daha düşük olduğu gösterilmiştir (60). Çok yüksek düzeyler orta seviyeli yüksekliklere göre daha çok VTE ile ilişkili olsa da, VTE ve COVID-19'a bağlı yüksekliğin ayrımını yapacak eşik değer belirlemek mümkün değildir. Ancak normal D-Dimer düzeyi olan, klinik olarak yüksek olasılıklı PE düşünülmeyen COVID-19 hastalarında akut trombüs varlığı ekarte edilebilir. 


\section{SONUÇ}

- COVID-19 pnömonisinin akciğerlerde fibrozis yapıp yapmadığı, eğer yapıyorsa hastanın yaşam kalitesini etkilemeyen ve solunum fonksiyon bozukluklarına neden olmayan lokalize fibrotik değişiklikler şeklinde mi, yoksa iPF'de olduğu gibi ciddi klinik sonuçlar doğuran progresif fibrotik akciğer hastalığı şeklinde mi olacağı konusunda yeterli kanıt yoktur.

- Hastaların hangi sıklıkta izlenmesi gerektiği konusunda bir görüş birliği olmamakla birlikte COVID-19 pnömonisinin radyolojik rezolüsyonun uzun sürebileceği bilinmektedir. Fibrotik sekellerin incelenmesi açısından hastalar 3, 6 ve 12. ayda semptomlar, SFT, DLCO ve akciğer grafisi ile değerlendirilmeli, gerekirse HRCT çekilmelidir. Restriktif bozukluğu ve tomografide interstisyel fibrozisi olan hastaların ise yıllık izlenmesi uygun olacaktır. Özellikle mekanik ventilasyon uygulanan, ağır viral pnömoni geçiren hastaların takibi konusunda daha dikkatli olunması gerekmektedir.

- Hipersensitivite pnömonisi ve otoimmun interstisyel pnömonilerde akciğer fibrozisi inflamasyonu takiben ortaya çıkar. Bu grup hastalıklar inflamasyon döneminde kortikosteroidlerden yarar görebilir. Ayrıca ARDS'de kortikosteroid kullanımının akciğerlerde kalıcı yapısal değişiklikleri önlediğini gösteren çalışmalar mevcuttur. Günümüzde COVID-19 pnömonisinde kortikosteroid kullanımının uzun dönem fibrotik komplikasyonları azalttığı veya önlediği, kullanım süresi, dozu konusunda kanıt olmamasına karşın yukarıda belirtilen bulgulara dayanılarak akut pnömoni dönemi sonrası hastalara 10-20 gün süre ile 20-30 mg/gün kortikosteroid verilmesi bir seçenek olabilir.

- Yürütülmekte olan çalışmalar dışında antifibrotik tedavilerin etkinliğini gösteren bir çalışma ve kanıt henüz bulunmamaktadır. Etkinliğini gösteren çalışmalar yayımlanıncaya kadar antifibrotik ilaçların COVID-19 sekellerinin tedavisinde kullanılması önerilmez. Diğer fibrotik interstisyel akciğer hastalıklardan elde edilen sonuçlar ışığında ancak yaygın, progresif fibrozis ile giden sekellerde antifibrotik tedavinin gündeme geleceği düşünülmektedir.
- COVID-19 hastalarında standart heparin (SH) veya düşük molekül ağırlıklı heparinler (DMAH) ile tromboflaksi gereklidir.

- Taburculukta VTE açısından yüksek riskli COVID19 hastalarında kanama riski dikkate alınarak profilaksinin DMAH veya DOAK (enoxaparin 6-14 gün, rivaroksaban 31-39 gün; betriksaban 35-42 gün boyunca) ile evde devam edilmesini önermektedirler.

- Pnömonisi olmayan ve COVID-19'u hafif geçiren olgular için tromboprofilaksi önerilmemektedir.

- Profilakside antiplatelet ve antiagregan tedavilerin etkinliğine dair kanıtlar yeterli olmadığından devam eden çalışmaların sonuçları yol gösterici olacaktır.

- Akut COVID-19 geçirirken pulmoner tromboemboli (PE) tanısı alan hastaların tedavi ve takipleri PE rehberlerindeki protokollere göre yapılmalıdır.

\section{KAYNAKLAR}

1. Spagnolo P, Balestro E, Aliberti S, Cocconcelli E, Biondini $D$, Della Casa G, et al. Pulmonary fibrosis secondary to COVID-19: a call to arms? Lancet Respir Med 2020; 8: 752-4.

2. World Health Organization (WHO). Coronavirus disease (COVID-19) pandemic. Available from: www.who.int/ emergencies/diseases/novel-coronavirus-2019

3. T.C. Sağlık Bakanlığı COVID-19 Bilgilendirme Sayfası. Available from: https://covid19.saglik.gov.tr/

4. Barisione E, Grillo F, Bal L, Bianchi R, Grosso M, Morbini $P$, et al. Fibrotic progression and radiologic correlation in matched lung samples from COVID-19 post-mortems. Virchows 2020; 28: 1-15.

5. Carsana L, Sonzogni A, Nasr A, Rossi RS, Pellegrinelli A, Zerbi $P$, et al. Pulmonary post-mortem findings in a series of COVID-19 cases from northern Italy: a two-centre descriptive study. Lancet Infect Dis 2020; 20: 1135-40.

6. Fang Y, Zhou J, Ding X, Ling G, Yu S. Pulmonary fibrosis in critical ill patients recovered from COVID-19 pneumonia: preliminary experience. Am J Em Med 2020; 38(10): 2134-8.

7. Pan Y, Guan H, Zhou S, Wang Y, Li Q, Zhu T, et al. Initial $C T$ findings and temporal changes in patients with the novel coronavirus pneumonia (2019-nCoV): a study of 63 patients in Wuhan, China. Eur Radiol 2020; 30: 3306-9.

8. Ye Z, Zhang $Y$, Wang $Y$, Huang $Z$, Song B. Chest CT manifestations of new coronavirus disease 2019 (COVID-19): a pictorial review. Eur Radiol 2020; 30: 4381-9. 
9. Wang Y, Dong C, Hu Y, Li C, Ren $Q$, Zhang $X$, et al. Temporal changes of $C T$ findings in 90 patients with COVID-19 pneumonia: a longitudinal study. Radiology 2020; 296: e55-e64.

10. Mo X, Jian W, Su Z, Chen M, Peng H, Peng P, et al. Abnormal pulmonary function in COVID-19 patients at time of hospital discharge. Eur Respir J 2020; 55: 2001217.

11. Daher A, Balfanz P, Cornelissen C, Müller A, Bergs I, Marx I, et al. Follow up of patients with severe coronavirus disease 2019 (COVID-19): Pulmonary and extrapulmonary disease sequelae. Respir Med 2020; 174: 106197.

12. Hu T, Liu Y, Zhao M, Zhuang $Q, X u L$, He Q. A comparison of COVID-19, SARS and MERS. Peer J 2020; 8: e9725.

13. Hui DS, Joynt GM, Wong KT, Gomersall CD, Li TS, Antonio $G$, et al. Impact of severe acute respiratory syndrome (SARS) on pulmonary function, functional capacity and quality of life in a cohort of survivors. Thorax 2005; 60: 401-9.

14. Zhang P, Li J, Liu H, Han N, Ju J, Kou Y, et al. Long-term bone and lung consequences associated with hospital-acquired severe acute respiratory syndrome: a 15-year follow-up from a prospective cohort study. Bone Research 2020; 8: 8 .

15. Hui DS, Wong KT, Ko FW, Tam LS, Chan DP, Woo J, et al. The 1-year impact of severe acute respiratory syndrome on pulmonary function, exercise capacity, and quality of life in a cohort of survivors. Chest 2005; 128: 2247-61.

16. Ngai JC, Ko FW, Susan SN, To KW, Tong M, Hui DS. The long-term impact of severe acute respiratory syndrome on pulmonary function, exercise capacity and health status. Respirology 2010; 15: 543-50.

17. Das KM, Lee EY, Singh R, Enani MA, Dossari KA, Gorkom $K V$, et al. Follow-up chest radiographic findings in patients with MERS-CoV after recovery. Indian I Radiol Imaging 2017; 27: 342-9.

18. Liu D, Zhang $W$, Pan F, Li L, Yang $L$, Zheng $D$, et al. The pulmonary sequalae in discharged patients with COVID19: a short-term observational study. Respir Res 202; 21: 125.

19. Raghu G, Wilson KC. COVID-19 interstitial pneumonia: monitoring the clinical course in survivors. Lancet Respir Med 2020: 8; 839-42.

20. George PM, Barratt SL, Condliffe R, Desai SR, Devaraj A, Forrest I, et al. Respiratory follow-up of patients with COVID-19 pneumonia. Thorax 2020; 0: 1-8.

21. Lechowicz K, Drozdzal S, Machaj F, Rosik J, Szostak B, Zegan-Bara M, et al. COVID-19: The potential treatment of pulmonary fibrosis associated with SARS-CoV-2 infection. J Clin Med 2020; 9: 1917.

22. Gentile F, Aimo A, Forfori F, Catapano G, Clemente A, Cademartiri F, et al. COVID-19 and risk of pulmonary fibrosis: the importance of planning ahead. Eur I Preven Cardiol 2020; 27(13): 1442-6.
23. Yu M, Liu Y, Xu D, Zhang R, Lan L, Xu H. Prediction of the development of pulmonary fibrosis using serial thin-section CT and clinical features in patients discharged after treatment for COVID-19 pneumonia. Korean / Radiol 2020; 21(6): 746-55.

24. Ojo AS, Balogun SA, Williams OT, Ojo OS. Pulmonary fibrosis in COVID-19 survivors: predictive factors and risk reduction strategies. Pulm Med 2020; 6175964.

25. Huang $W, W u Q$, Chen Z, Xiong Z, Wang K, Tian J, et al. The potential indicators for pulmonary fibrosis in survivors of severe COVID-19. J Infect 2020; (20)30632-0.

26. World Health Organization (WHO). Corticoteroids for COVID-19. Available from: https://www.who.int/publications/i/item/WHO-2019-nCoV-Corticosteroids-2020.1

27. Villar J, Confalonieri M, Pastores SM, Meduri GM. Rationale for prolonged corticosteroid treatment in the acute respiratory distress syndrome caused by coronavirus disease 2019. Crit Care Expl 2020; 2: e0111.

28. Buckley LF, Wohlford GF, Ting C, Alahmed A, Van Tassell $B W$, Abbate $A$, et al. Role for anti-cytokine therapies in severe coronavirus disease 2019. Crit Care Expl 2020; 2: e0178.

29. Richeldi L, du Bois RM, Raghu G, Azuma A, Brown KK, Costabel $U$, et al. Efficacy and safety of nintedanib in Idiopathic pulmonary fibrosis. N Engl I Med 2014; 370: 207182.

30. Noble PW, Albera C, Bradford WZ, Costabel U, Glassberg MK, Kardatzke D, et al. Pirfenidone in patients with idiopathic pulmonary fibrosis (CAPACITY): two randomised trials. Lancet 2011; 377: 1760-9.

31. Flaherty $K R$, Wells $A U$, Cottin V, Devaraj A, Walsh SLF, Inoue $Y$, et al. Nintedanib in progressive fibrosing interstitial lung diseases. N Engl I Med 2019: 381(18): 1718-27.

32. Maher TM, Corte TJ, Fischer A, Kreuter M, Lederer DJ, Molina-Molina $M$, et al. Pirfenidone in patients with unclassifiable progressive fibrosing interstitial lung disease: a double-blind, randomised, placebo-controlled, phase 2 trial. Lancet Respir Med 2020; 8(2): 147-57.

33. George PM, Wells AU, Jenkins RG. Pulmonary fibrosis and COVID-19: the potential role for antifibrotic therapy. Lancet Respir Med 2020; 8: 807-15.

34. Seifirad S. Pirfenidone: a novel hypothetical treatment for COVID-19. Med Hypotheses 2020; 144: 110005.

35. Ferrara F, Granata G, Pelliccia C, La Porta R, Vitiello A. The added value of pirfenidone to fight inflammation and fibrotic state induced by SARS-CoV-2 anti-inflammatory and anti-fibrotic therapy could solve the lung complications of the infection? Eur J Clin Pharma 2020; 76: 1615-8.

36. Chaudhary $S$, Natt B, Bime $C$, Knox KS, Glassberg MK. Antifibrotics in COVID-19 lung disease: let us stay focused. Front Med 2020; 7: 539. 
37. Delpino MV, Quarleri J. SARS-CoV-2 pathogenesis: imbalance in the renin-angiotensin system favors lung fibrosis. Front Cell Infect Microbiol 2020; 10: 340.

38. Barut F, Ozacmak VH, Turan I, Sayan-Ozacmak H, Aktunc E. Reduction of acute lung Injury by administration of spironolactone after intestinal Ischemia and reperfusion in rats. Clin Investig Med Med 2016; 39: e15-e24.

39. Yavas G, Yavas C, Celik E, Sen E, Ata O, Afsar RE. The impact of spironolactone on the lung injury induced by concomitant trastuzumab and thoracic radiotherapy. Int J Radiat Res 2019; 17(1): 87-95.

40. Nadkarni GN, Lala A, Bagiella E, Chang HL, Moreno PR, Pujadas E, et al. Anticoagulation, bleeding, mortality, and pathology in hospitalized patients with COVID-19. I Am Coll Cardiol 2020; 76: 1815-26.

41. UpToDate. Cuker A, Peyvandi F. Coronavirus disease 2019 (COVID-19): hypercoagulability. Available from: www. up todate.com / contents / coronavirus-disease-2019-covid-19-hypercoagulability.

42. Spyropoulos AC, Levy JH, Ageno W, Connors IM, Hunt BJ, Iba $T$, et al. Scientific and Standardization Committee Communication: Clinical guidance on the diagnosis, prevention, and treatment of venous thromboembolism in hospitalized patients with COVID-19. I Thromb Haemost 2020; 18(8): 1859-65.

43. Klok FA, Kruip MJHA, van der Meer NJM, Arbous MS, Gommers DAMPJ, Kant KM, et al. Incidence of thrombotic complications in critically ill ICU patients with COVID19.Thromb Res 2020; 191: 145-7.

44. Cui S, Chen S, Li X, Liu S, Wang F. Prevalence of venous thromboembolism in patients with severe novel coronavirus pneumonia. J Thromb Haemost 2020; 18(6): 1421-4.

45. O'Sullivan JM, Gonagle DM, Ward SE, Preston RJS, O'Donnell JS. Endothelial cells orchestrate COVID-19 coagulopathy. Lancet Haematol 2020; 7(8): e553-e5.

46. Tang N, Li D, Wang X, Sun Z. Abnormal coagulation parameters are associated with poor prognosis in patients with novel coronavirus pneumonia. I Thromb Haemost 2020; 18: 844-7.

47. Fogarty $H$, Townsend L, Cheallaigh CN, Bergin C, MartinLoeches I, Browne P, et al. COVID-19 coagulopathy in Caucasian patients. Br J Haematol 2020; 189: 1044-9.

48. Ackermann M, Verleden SE, Kuehnel M, Haverich A, Welte $T$, Laenger $F$, et al. Pulmonary vascular endothelialitis, thrombosis, and angiogenesis in COVID-19. N Engl I Med 2020; 383(2): 120-8.

49. McGonagle D, O'Donnell JS, Sharif K, Emery P, Bridgewood C. Immune mechanisms of pulmonary intravascular coagulopathy in COVID-19 pneumonia. Lancet Rheumatol 2020; 2: e437-e45.
50. Goshua G, Pine AB, Meizlish ML, Chang C-Hong, Zhang $H$, Bahel $P$ et al. Endotheliopathy in COVID-19- associated coagulopathy: evidence from a single-centre, cross-sectional study. Lancet Haematol 2020; 7(8): e575-e82.

51. Moores LK, Tritschler T, Brosnahan S, Carrier M, Collen JF, Doerschug K, et al. Prevention, diagnosis, and treatment of VTE in patients with coronavirus disease 2019: CHEST guideline and expert panel report. Chest 2020; 158(3): 1143-63.

52. COVID-19 Treatment Guidelines. Coronavirus disease 2019 (COVID-19) treatment guidelines. Available from: https://www.covid19treatmentguidelines.nih.gov/ Accessed date: 10/7/2020.

53. T.C. Sağlık Bakanlığı, Halk Sağlığı Genel Müdürlüğü. COVID-19 (SARS-CoV-2 enfeksiyonu) antisitokin-antiinflamatuar tedaviler, koagülopati yönetimi. Available from: https://covid19.saglik.gov.tr. Accessed date: 2 Kasım 2020 .

54. Barnes GD, Burnett A, Allen A, Blumenstein M, Clark NP, Cuker $A$, et al. Thromboembolism and anticoagulant therapy during the COVID-19 pandemic: interim clinical guidance from the anticoagulation forum. I Thromb Thrombolysis 2020; 50(1): 72-81.

55. British Thoracic Society. BTS Guidance on Venous Thromboembolic Disease in Patients with COVID-19. Available from: www.brit-thoracic.org.uk/document-library/quality-improvement/covid-19/bts-guidance-on-venous-thromboembolic-disease-in-patients-with-covid-19. V2.0 Accessed date: 4 May 2020.

56. Rosenberg D, Eichorn A, Alarcon M, McCullagh $L$, McGinn T, Spyropoulos AC. External validation of the risk assessment model of the International Medical Prevention Registry on Venous Thromboembolism (IMPROVE) for medical patients in a tertiary health system. I Am Heart Assoc 2014; 3(06): e001152.

57. Gerotziafas GT, Catalano M, Colgan MP, Pecsvarady Z, Wautrecht JC, Fazeli B, et al. Guidance for the Management of Patients with Vascular Disease or Cardiovascular Risk Factors and COVID-19: Position Paper from VAS-European Independent Foundation in Angiology/Vascular Medicine. Thromb Haemost 2020; 120: 1597-628.

58. George $P M$, Barratt $S L$, Condliffe $R$, Desai $S R$, Devaraj $A$, Forrest I, et al. Respiratory follow-up of patients with COVID-19 pneumonia. Thorax 2020; 75: 1009-16.

59. Guan $W-J, N i Z-Y, H u Y$, Liang $W-H$, Ou C-Q, He J-X, et al. Clinical characteristics of coronavirus disease 2019 in China. N Engl J Med Overseas Ed 2020; 382: 1708-20.

60. Tang N, Li D, Wang X, Sun Z. Abnormal coagulation parameters are associated with poor prognosis in patients with novel coronavirus pneumonia. J Thromb Haemost 2020; 18: 844-7. 